\title{
MENGENALI DAN MENGEMBANGKAN POTENSI KECERDASAN JAMAK ANAK SEJAK DINI SEBAGAI TONGGAK AWAL MELAHIRKAN GENERASI EMAS
}

\author{
Mubiar Agustin ${ }^{1}$
}

\begin{abstract}
ABSTRAK
Semua anak adalah berbakat. Tiap-tiap anak terlahir ke dunia dengan potensi yang unik, jika dipupuk dengan benar,dapat turut memberikan sumbangan bagi dunia yang lebih baik. Tantangan terbesar adalah menyingkirkan batu besar yang menghalangi jalan mereka dalam menemukan,mengembangkan, dan merayakan anugerah yang mereka miliki itu

(Thomas Armstrong)
\end{abstract}

\section{A. PENDAHULUAN}

Asumsi tentang adanya potensi kecerdasan jamak pada anak muncul berdasarkan paradigma bahwa setiap anak yang lahir telah memiliki potensi genius. Thomas Armstrong menegaskan dalam tulisannya yang bertajuk natural genius of children bahwa setiap anak adalah genius. Setiap anak dilahirkan dengan kemampuan tertentu. Setiap anak dilahirkan ke dunia dengan kekaguman, keingintahuan, spontanitas, vitalitas, fleksibilitas, dan banyak lagi kesenangan lain baginya. Anak kecil akan secara langsung menguasai sistem simbol yang rumit, otak cemerlang, kepribadian sensitif dan akselerasi terhadap setiap stimulasi, tanpa pendidikan secara formal. Dalam hal ini, adalah kewajiban orang tua di rumah dan guru di taman kanak-kanak untuk memelihara setiap kecerdasan anak sejak dini. Kejeniusan alami tersebut hendaklah dipelihara, dan ditumbuhkembangkan secara optimal oleh orang dewasa.

Menurut Howard Gardner kecerdasan anak bukan hanya berdasarkan pada skor standar semata (Tes IQ), melainkan dengan ukuran kemampuan yang diuraikan sebagai berikut (1) Kemampuan untuk menyelesaikan masalah yang terjadi dalam kehidupan individu; (2) Kemampuan untuk menghasilkan persoalan-persoalan baru untuk diselesaikan; dan (3) Kemampuan untuk menciptakan sesuatu atau memberikan penghargaan dalam budaya seseorang.

Teori kecerdasan jamak (multiple intelligences) dikembangkan oleh Gardner berdasarkan pandangannya bahwa kecerdasan pada saat sebelumnya hanya dilihat dari segi linguistik dan logika. Padahal, ada berbagai kecerdasan dan orang-orang dengan kecerdasan tipe lain yang tidak diperhatikan. Kecerdasan jamak adalah sebuah penilaian yang dilihat secara deskriptif bagaimana individu menggunakan kecerdasannya untuk memecahkan masalah dan menghasilkan sesuatu. Pendekatan ini merupakan suatu alat yang dipergunakan untuk melihat pikiran manusia mengoperasikan lingkungannya, baik itu berhubungan dengan benda-benda yang konkret ataupun yang abstrak.

${ }^{1}$ Dosen Prodi PGPAUD Sekolah Pascasarjana UPI 
Lebih lanjut, bagi Gardner tidak ada anak bodoh, yang ada anak yang menonjol pada satu atau beberapa jenis kecerdasan. Dengan demikian, dalam menilai dan menstimulasi kecerdasan anak, orang tua dan guru selayaknya dengan jeli dan cermat merancang sebuah metode khusus yang dapat membantu merangsang potensi kecerdasan jamak anak tersebut.

\section{B. APAKAH KECERDASAN JAMAK ITU ?}

Kecerdasan Jamak merupakan istilah dalam kajian tentang kecerdasan yang diprakarsai oleh seorang pakar pendidikan Amerika Serikat bernama Howard Gardner. Terdapat keragaman terjemahan tentang Multiple Intelligences ini, sebagian orang menerjemahkan dengan kecerdasan ganda, kecerdasan majemuk dan kecerdasan jamak. Dalam tulisan ini yang dipergunakan sebagai terjemahan multiple intelligences adalah kecerdasan jamak.

Teori kecerdasan jamak (multiple intelligences), bukanlah teori pertama yang menyatakan tentang adanya kecerdasan selain kecerdasan intelektual (IQ) pada diri individu. Sejalan dengan berkembangnya peradaban manusia, maka mulai terjadi juga pergeseran paradigma dalam menerjemahkan arti kecerdasan. Seperti kecerdasan emosi (emosional intelligence) yang diprakarsai oleh Daniel Goleman (1995), kecerdasan spiritual (spiritual inteligence) yang dikembangkan oleh Ian Marshal dan Danah Johar (1993), serta Emotional Spiritual Quetions yang dicetuskan oleh Utsman Najati dan Ary Ginanjar Agustian (1996, 2000).

Gardner memaparkan beberapa kelebihan teori Kecerdasan Jamak (Multiple Intelligences) sebagai berikut : (1) memiliki dukungan riset multidisiplin yakni antropologi, psikologi kognitif, psikologi perkembangan, psikometri, studi biografi, fisiologi hewan dan neuroanatomi; dan (2) apabila dibandingkan dengan teori kecerdasan lain, jumlah kecerdasan dalam kecerdasan jamak beragam, sehingga akan tampak "keadilan" dalam menentukan dominasi kecerdasan tertentu untuk tiap individu.

Menurut Gardner kecerdasan jamak adalah kemampuan untuk menyelesaikan masalah atau menghasilkan produk yang dibuat dalam satu atau beberapa budaya. Secara lebih terperinci Gardner menguraikan sebagai berikut : (1) kemampuan untuk menyelesaikan dan menemukan solusi masalah dalam kehidupan nyata; (2) kemampuan untuk menghasilkan persoalan-persoalan baru untuk diselesaikan; dan (3) kemampuan untuk menciptakan sesuatu yang akan menimbulkan penghargaan dalam budaya seseorang.

Lebih lanjut, menurut Gardner kecerdasan jamak didasarkan pada potensi biologis, yang kemudian diekspresikan sebagai hasil dari faktor-faktor genetik dan lingkungan yang saling mempengaruhi. Secara umum, individu normal mampu menunjukkan bauran beberapa kecerdasan. Kecerdasan tidak pernah dijumpai dalam bentuk murni. Sebaliknya, kecerdasan tertanam dalam berbagai sistem simbol, seperti bahasa, gambar, peta, notasi musik, dan simbol matematika.

Gardner pada sisi yang lain menjelaskan bahwa kecerdasan jamak memiliki karakteristik konsep sebagai berikut ini : (1) semua intelegensi itu berbeda-beda, tetapi semuanya sederajat. Dalam pengertian ini, tidak ada kecerdasan yang lebih baik atau lebih penting dari kecerdasan yang lain; (2) semua kecerdasan dimiliki 
manusia dalam kadar yang tidak persis sama. Semua kecerdasan dapat dieksplorasi, ditumbuhkan dan dikembangkan secara optimal; (3) terdapat banyak indikator kecerdasan dalam tiap-tiap kecerdasan. Dengan latihan, seseorang dapat membangun kekuatan kecerdasan yang dimiliki dan menipiskan kelemahankelemahan; (4) semua kecerdasan yang berbeda-beda tersebut bekerja sama untuk mewujudkan aktivitas yang dilakukan individu. Satu kegiatan mungkin memerlukan lebih dari satu kecerdasan, dan satu kecerdasan dapat digunakan dalam berbagai bidang; (5) semua jenis kecerdasan tersebut ditemukan di seluruh/semua lintas kebudayaan di seluruh dunia dan kelompok usia; dan (6) saat seseorang dewasa, kecerdasan diekspresikan melalui rentang pencapaian profesi dan hobi. Kecerdasan logika-matematika yang dimulai sebagai kemampuan pola pada masa balita dan berkembang menjadi penguasaan simbolik pada masa anak-anak, misalnya akhirnya mencapai kematangan ekspresi dalam wujud profesi sebagai ahli matematika, akuntan dan ilmuwan.

Esensi teori kecerdasan jamak (multiple intellegences) menurut Gardner adalah menghargai keunikan setiap individu, berbagai variasi cara belajar, mewujudkan sejumlah model untuk menilai mereka dan cara yang hampir tak terbatas untuk mengaktualisasikan diri di dunia ini.

\section{MENGENALI KARAKTERISTIK KECERDASAN JAMAK ANAK}

Teori kecerdasan jamak (multiple intelegence) dikembangkan tahun 1983 oleh Howard Gardner. Gardner berpendapat bahwa kecerdasan yang berdasarkan pada tes IQ, yang merupakan pandangan tradisional, amatlah terbatas. Gardner mengemukakan definisi kecerdasan yang berbeda untuk mengukur cakupan yang lebih luas tentang potensi manusia, baik anak-anak ataupun orang dewasa. Ia membaginya dalam 8 (delapan) jenis kecerdasan.

Kedelapan kecerdasan tersebut bisa saja dimiliki oleh individu, hanya saja dalam taraf yang berbeda. Selain itu, kecerdasan ini juga tidak berdiri sendiri, terkadang bercampur dengan kecerdasan lain. Misalnya saja, bila anak pintar bernyanyi sebagai kecerdasan musikal, ia juga biasanya akan cerdas dalam gerak tubuh pada saat mengikuti dan menyesuaikan dengan ritme /alunan musik yang didendangkan.

Secara umum deskripsi tentang kecerdasan jamak pada anak beserta indikatornya yang dicetuskan oleh Howard Gardner diuraikan sebagai berikut ini.

\section{Kecerdasan Linguistik/Verbal}

Kecerdasan ini merupakan suatu kemampuan untuk menggunakan kata-kata secara efektif, baik lisan ataupun tulisan. Pada kecerdasan ini termasuk kemampuan untuk memanipulasi sintaks atau struktur bahasa, fonologi atau bunyi dalam bahasa, semantik atau pemaknaan bahasa, dan dimensi pragmatik atau penggunaan secara praktis bahasa. Di antara penggunaannya termasuk retorik (mempengaruhi orang lain untuk bertindak), menemonik (menggunakan bahasa untuk mengingat informasi), menjelaskan (menggunakan bahasa untuk menjelaskan) dan metabahasa (menggunakan bahasa untuk membahasnya sendiri). Adapun ciri-cirinya yang menonjol tampak pada aktivitas anak sebagai berikut ini. (a) Suka menyanyikan 
lagu-lagu yang sederhana, mengetahui beberapa sajak serta menyenangi permainan dengan jari jemari; (b) Senang berbicara di depan teman-teman sebayanya; (c) Suka bercerita dengan teman-teman sebaya atau anggota keluarga; (d) Mengeja kata-kata dengan mudah dan tepat; (e) Mempelajari kata-kata baru dengan cepat, khususnya jika berkaitan dengan pengalamannya sendiri; dan (f) Memiliki kosakata yang lebih banyak dan luas dari anak seusianya.

\section{Kecerdasan Logika-Matematika}

Kemampuan menggunakan bilangan secara efektif dan tinggi dalam berargumentasi. Dalam kecerdasan ini termasuk kepekaan terhadap pola-pola logis dan hubungan-hubungannya, pernyataan dan proporsi. Jenis proses yang digunakan dalam pemecahan logika matematika termasuk : kategorisasi, klasifikasi, inferensi, generalisasi kalkulasi dan tes hipotesis. Adapun ciri-cirinya pada anak adalah sebagai berikut ini: (a) memiliki kemampuan dalam mengolah angka atau kemahiran menggunakan logika; (b) tertarik memanipulasi lingkungan serta cenderung suka menerapkan strategi coba-ralat; (c) memiliki rasa ingin tahu yang besar terhadap suatu peristiwa atau pengalaman yang dialami; dan (d) suka menyusun permainan yang sifatnya kategori dan hierarki.

\section{Kecerdasan Spasial}

Kemampuan untuk mempersepsikan dunia visual spasial secara tepat dan kemampuan mentransformasikan pada persepsi-persepsi demikian. Kecerdasan ini melibatkan kepekaan terhadap warna, garis, bentuk, ukuran, luas dan hubunganhubungan yang ada pada unsur itu. Di dalamnya termasuk kemampuan memvisualisasikan, dan secara grafis menggambarkan ide-ide visual dan spasial, serta secara tepat mengorientasikan diri sendiri ke dalam matriks spasial. Adapun ciri-cirinya yang tampak pada aktivitas anak adalah sebagai berikut ini: (a) memiliki kepekaan terhadap warna, garis, bentuk, ruang dan bangunan; (b) memiliki kemampuan membayangkan sesuatu, melahirkan ide secara visual dan spasial; (c) memiliki kemampuan mengenali identitas objek ketika objek itu ada pada sudut pandang yang berbeda; (d) mampu memperkirakan jarak dan keberadaan dirinya dengan sebuah objek; (e) suka mencoret-coret, membentuk gambar, mewarnai dan menyusun unsur-unsur bangunan; dan (f) dapat membentuk sesuatu yang memiliki makna bagi dirinya.

\section{Kecerdasan Kinestetik (bodily-kinestetic)}

Kemampuan dalam menggunakan keseluruhan potensi tubuh untuk mengekspresikan ide-ide dan perasaan. Memiliki kemampuan untuk menggunakan tangan untuk memproduksikan atau mentransformasikan hal/benda. Dalam hal ini, termasuk keterampilan khusus seperti koordinasi, keseimbangan, kekuatan, fleksibilitas, dan kecepatan. Adapun ciri-cirinya yang menonjol pada anak adalah sebagai berikut ini: (a) menonjol dalam kemampuan olah raga dibandingkan dengan teman-teman sebayanya; (b) cenderung suka bergerak, tidak bisa duduk diam berlama-lama, mengetuk-ngetuk sesuatu, dan suka meniru gerak atau tingkah laku yang menarik perhatiannya; (c) senang pada aktivitas yang mengandalkan kekuatan 
gerak, seperti memanjat, berlari, melompat atau berguling; (d) cepat dan tangkas dalam menguasai tugas-tugas kerajinan tangan seperti melipat, memotong, menggunting dan mencocok; (e) memiliki koordinasi tubuh yang baik, gerakangerakan yang seimbang, luwes dan cekatan; (f) senang menyentuh barang-barang dan membongkar pasang barang dan mainan; (g) secara artistik mereka memiliki kemampuan menari dan menggerakkan tubuh mereka dengan luwes dan lentur.

\section{Kecerdasan Musikal}

Kemampuan mempersepsikan, membedakan dan mengekspresikan bentuk bentuk musik. Kecerdasan ini melibatkan kepekaan terhadap ritme, melodi, dan bunyi musik lainnya dari sesuatu ciptaan musik. Termasuk dalam kecerdasan ini adalah memiliki kemampuan pemahaman musik, baik pemahaman dari atas ke bawah atau sebaliknya ataupun kedua-duanya (global ataupun intuitif, ataupun dalam analitik dan teknikal). Adapun ciri-cirinya yang dapat dicermati adalah sebagai berikut ini: (a) cepat menghapal lagu-lagu dan bersemangat ketika dikenalkan kepadanya lagu; (b) menikmati lagu dan menggerakan tubuh sesuai dengan irama musik tersebut; (c) mengetuk-ngetukkan benda ke meja pada saat menulis atau menggambar; (d) senang bermain alat musik atau bahkan bermusik dengan benda-benda tak terpakai; (e) senang bernyayi, bersenandung atau bersiul; (f) sudah mengenali suara-suara yang ada disekitarnya seperti suara sepeda motor, burung, gemercik air ataupun tiupan angin; (g) mudah mengenali suatu lagu hanya dengan mendengar nada-nada pertama lagu tersebut; dan (h) peka terhadap suarasuara di lingkungan sekitar.

\section{Kecerdasan Interpersonal}

Kemampuan mempersepsikan dan membedakan dalam modus, maksud tertentu, motivasi dan perasaan dari orang lain. Di dalam kecerdasan ini termasuk kepekaan ekspresi muka, suara dan gerak-gerik. Memiliki kemampuan untuk membedakan hal-hal dari banyak jenis tanda-tanda interpersonal. Memiliki kemampuan untuk bereaksi secara efektif terhadap tanda-tanda demikian secara pragmatik. Ciri-ciri yang menonjol dari kecerdasan ini adalah sebagai berikut ini: (a) kemampuan berempati pada teman-temannya; (b) mengorganisasi teman-temannya untuk melakukan tugas; (c) mampu mengenali dan membaca pikiran orang lain; (d) memiliki banyak teman dan mampu menjalin hubungan dengan teman-temannya; (e) cenderung mudah memahami perasaan orang lain; (f) sering menjadi pemimpin di antara teman-temannya; dan (g) memiliki perhatian yang besar kepada temantemannya sehingga acapkali mengetahui berita-berita di seputar mereka.

\section{Kecerdasan Intrapersonal}

Berpengetahuan sendiri dan kemampuan untuk bertindak secara adaptif atas dasar pengetahuan sendiri. Dalam kecerdasan ini termasuk memiliki gembaran akurat tentang diri sendiri (kekuatan sendiri dan keterbatasan sendiri). Kesadaran tentang perasaan dalam diri sendiri, intensi, motivasi, temperamen dan keinginankeinginan, dan kemampuan untuk disiplin diri sendiri, pemahaman sendiri dan percaya diri.Ciri-ciri yang tampak dari kecerdasan ini adalah sebagai berikut ini: (a) 
memperlihatkan sikap mandiri, memiliki kemauan yang keras, penuh percaya diri dan memiliki tujuan tertentu; (b) bersikap realistis terhadap kekuatan dan kelemahan diri sendiri; (c) tidak banyak mengalami masalah apabila harus belajar sendiri; (d) mampu belajar dari kegagalan dan memahami kelebihan serta kelemahan diri sendiri; (e) mampu menghargai diri sendiri dan memiliki kemampuan untuk berkreasi dan berhubungan secara dekat; dan (f) dapat dengan tepat mengekspresikan perasaan.

\section{Kecerdasan Naturalis}

Kecerdasan ini berkaitan dengan seluruh yang terdapat di alam dunia ini. Kecerdasan ini sangat sensitif untuk disimulasikan dengan semua aspek alam, mencakup bertanam, binatang, cuaca, dan gambaran fisik dari bumi. Di dalamnya mencakup keterampilan mengenali berbagai kategori dan varitas dari binatang, serangga, tanaman dan bunga. Ini mencakup kemampuan menanam sesuatu, memelihara dan melatih binatang. Ini juga mencakup kepekaan untuk dan mencintai bumi, sebagaimana keinginan untuk memeliharanya dan melindungi sumber-sumber alam. Ciri-cirinya yang tampak pada perilaku anak adalah sebagai berikut ini: (a) cenderung menyukai alam terbuka, akrab dengan hewan peliharaan, dan menghabiskan waktu dekat tempat-tempat hewan; (gemar mengoleksi mainan binatang tiruan; (b) menikmati komunikasi dengan binatang piaraan dan memberi mereka makanan; (c) memiliki perhatian yang relatif besar terhadap binatang, tumbuhan dan alam; (d) tidak takut memegang atau menyentuh binatang dan bahkan cenderung ingin selalu dekat; (e) memahami topik-topik tentang sistem kehidupan; dan (f) terlibat dalam hobi atau proyek yang dikerjakan sendiri.

\section{Upaya Mengembangkan Potensi Kecerdasan Jamak anak}

Menurut Gardner anak yang cerdas dalam linguistik mungkin telah menguasai kemampuan membaca dan menulis lebih dini daripada anak-anak seusianya. Cara belajar terbaik bagi anak-anak yang cerdas dalam bidang linguistik adalah dengan mengucapkan, mendengarkan, dan melihat tulisan. Cara terbaik memotivasi mereka adalah dengan cara mengajak mereka berbicara, menyediakan banyak buku-buku, rekaman, serta menciptakan peluang mereka untuk menulis dan membaca.

Ditinjau dari sisi media pembelajaran, perlu disediakan peralatan yang mendorong anak-anak untuk membuat tulisan, menyediakan tape recorder, mesin ketik, atau key board untuk belajar mengidentifikasi huruf dalam kata-kata. Selain itu, berikan dongeng pada anak-anak dan berikan tanggung jawab. Sesekali, membawa anak-anak ke toko buku atau perpustakaan merupakan langkah yang tepat.

Adapun terkait dengan kecerdasan linguistik, Menurut Gardner, kecerdasan ini "meledak" pada awal masa kanak-kanak dan tetap bertahan hingga usia lanjut. Kaitannya dengan sistem neurologis, kecerdasan ini terletak pada lobus temporal yang berkaitan dengan memori, emosi, pendengaran dan bahasa atau disebut juga dengan istilah area pengendali ucapan (motor speech area). Tentunya stimulasi terhadap kecerdasan linguistik sangat penting,karena kecerdasan ini sangat diperlukan dalam hampir semua bidang kehidupan. Tidak ada satu profesi pun 
yang dapat dilepaskan dari pemanfaatan dan peran bahasa dalam berbagai variasi bentuknya.

Kecerdasan linguistik ini dapat dikembangkan dengan mempraktikan aktivitasaktivitas sebagai berikut : (a) mengajak anak berbincang-bincang tentang kejadian, benda ataupun aktivitas yang dilakukan anak; (b) membacakan cerita tentang hewan, tumbuhan ataupun tokoh-tokoh yang sudah dikenal anak; (c) mengajak anak bermain huruf dan angka; (d) merangkai cerita; (e) berdiskusi dan bermain peran; dan (f) memperdengarkan lagu anak-anak.

Sedangkan upaya mengembangkan kecerdasan matematis-logis dapat dilakukan dengan cara memberikan materi-materi konkret yang dapat dijadikan bahan percobaan seperti permainan mencampur warna, permainan aduk garam, aduk pasir. Kecerdasan matematis logis dapat juga ditumbuhkan melalui interaksi positif yang mampu membangkitkan rasa ingin tahu anak. Oleh karena itu, guru atau orang tua harus dapat menjawab pertanyaan - pertanyaan anak dan memberikan penjelasan logis. Selain itu, perlu diberikan permainan-permainan yang merangsang logika anak seperti maze, permainan misteri, permainan yang menggunakan kemampuan membandingkan, dan permainan yang membutuhkan kemampuan memecahkan masalah. Apabila perlu, ajaklah anak-anak untuk mendatangi tempattempat yang dapat mendorong pemikiran ilmiah, seperti ke tempat pameran komputer ataupun museum.

Guru dan orang tua dapat merangsang kecerdasan spasial dengan melakukan berbagai program seperti melukis, membentuk sesuatu dengan plastisin, mengecap dan menyusun potongan gambar. Dalam hal ini, guru pun perlu menyediakan berbagai fasilitas yang memungkinkan anak untuk mengembangkan daya imajinasi mereka. Lwin seorang pakar perkembangan anak asal Singapora menegaskan bahwa ketika guru dan orang tua mengajarkan kepada anak untuk benar-benar memperhatikan apa yang dia lihat di sekitarnya dan untuk menciptakan secara konstruktif gambaran dalam pikirannya menggunakan imajinasinya, maka guru dan orang tua pada akhirnya akan menemukan bahwa anak akan semakin kreatif. Hal ini karena visualisasi kreatif dan imajinasi merupakan dua aspek utama kecerdasan spasial dan menjadi dasar pemikiran kreatif.

Sedangkan secara posisi letak otak, kecerdasan spasial menurut Gardner terletak di lokasi otak bagian belakang hemisfer kanan. Kecerdasan ini berkaitan dengan kemampuan imajinasi anak. Janes Beaty pakar pendidikan anak asal Amerika menegaskan bahwa daya imajinasi anak akan membantu perkembangan potensi anak dalam bidang keterampilan intelektual, keterampilan sosial, keberbahasaan, dan juga aspek kreativitas.

Adapun stimulasi kecerdasan kinestetis-jasmani terjadi pada saat anak bermain. Pada saat bermain itulah anak berusaha melatih koordinasi otot dan gerak. Adapun wilayah-wilayah yang dapat dijadikan stimulasi oleh guru dan orang tua dalam mengembangkan kecerdasan kinestetis-jasmani adalah sebagai berikut ini: (a) koordinasi mata-tangan dan mata-kaki, seperti menggambar, menulis, memanipulasi objek, menaksir secara visual, melempar, menendang, dan menangkap; (b) keterampilan lokomotor, seperti berjalan, berlari, melompat, berbaris, meloncat, mencongklak, merayap, berguling dan merangkak; (c) keterampilan nonlokomotor, 
seperti membungkuk, menjangkau, memutar tubuh, merentang, mengayun, berjongkok, duduk dan berdiri; dan (d) kemampuan mengontrol dan mengatur tubuh seperti menunjukkan kesadaran tubuh, kesadaran ruang, kesadaran ritmik, keseimbangan kemampuan untuk mengambil start, kemampuan untuk menghentikan dan mengubah arah.

Selaras dengan pendapat di atas, Jalaludin Rakhmat atau Kang Jalal mengkritisi tentang adanya hubungan antara gerakan dengan koordinasi otak. Ia memaparkan bahwa gerakan mengaktifkan perkembangan corpus callosum (jembatan antara dua bagian serebrum). Menurut Rakmat inilah yang menyebabkan dua bagian tubuh bisa bekerja sama, termasuk tangan, kaki, mata dan pendengaran. Oleh karenanya, lebih lanjut ditegaskan bahwa dengan stimulasi yang seimbang, indera akan mampu mengakses lingkungan secara lebih luas dan kedua bagian tubuh dapat bergerak dengan cara yang lebih terintegrasi untuk kegiatan yang lebih efisien.

Guru dan orang tua dalam kegiatan bermain dapat memfasilitasi anak-anak yang memiliki kecerdasan ini dengan memberi kesempatan pada mereka untuk bergerak. Kegiatan dapat dirancang sedemikian rupa sehingga anak-anak leluasa bergerak dan memiliki peluang untuk mengaktualisasikan dirinya secara bebas. Kegiatan pun dapat dilakukan di luar ruangan seperti meniti tangga, berjalan satu kaki, senam irama, merayap, dan lari jarak pendek. Permainan yang bermuatan akademis sangat membantu anak-anak menyalurkan kebutuhan mereka untuk bergerak.

Menurut Gardner hampir semua anak memiliki kecerdasan musikal. Dengan stimulasi yang tepat, kemampuan musik anak akan terasah dan berkembang. Sebaliknya potensi musikal akan "mati" apabila tidak di stimulasi dan tidak dieksplorasi lebih lanjut. Oleh karena itu, guru dan orang tua perlu memfasilitasi anak supaya dapat berekspresi secara musikal melalui salam berirama, tepuk bernada, dan mungkin juga dengan menggunakan media-media yang sudah tidak terpakai lagi. Seperti kaleng bekas atau botol air minum mineral.

Adapun manfaat pengembangan kecerdasan musikal bagi anak adalah membantu (a) meningkatkan kreativitas dan imajinasi, musik memiliki sifat unik yang membuka pintu gerbang memasuki pikiran dan wawasan yang baru. Musik melatih seluruh otak, karena ketika mendengarkan sebuah lagu, otak kiri (bahasa, logika, matematika, dan akademik) memproses lirik, sementara itu otak kanan ( irama, persamaan bunyi, gambar, emosi, dan kreativitas) memproses musik; (b) ada bukti ilmiah yang mengaitkan musik dengan kecerdasan yang meningkat dan prestasi di sekolah yang meningkat pada anak-anak kecil. Musik telah berpengaruh terhadap peningkatan kemampuan pemikiran matematis, khususnya keterampilan pemikiran yang bersifat abstrak pada anak-anak; dan (c) musik dapat merangsang pikiran modern dan membantu meningkatkan daya ingat.

Kecerdasan interpersonal anak dapat distimulasi melalui kegiatan bermain. Selama bermain anak-anak berinteraksi dengan sebaya, guru dan orang tua mereka. Stimulasi tersebut dapat terjadi Karena pada saat bermain anak-anak : (a) mempraktikan keterampilan berkomunikasi baik verbal maupun nonverbal dengan cara menegosiasikan peran, mencoba memperoleh keuntungan saat bermain atau mengapresiasi perasaan teman lain; (b) merespon perasaan teman sepermainan di 
samping menunggu giliran dan berbagi materi serta pengalaman; (c) bereksperimen dengan peran-peran di rumah, sekolah dan komunitas dengan menjalin kontak dengan kebutuhan dan kehendak orang lain; dan (d) mencoba melihat sudut pandang orang lain. Begitu anak bersentuhan dengan konflik tentang ruang, waktu, materi dan aturan, mereka membangun strategi resolusi konflik secara positif.

Anak-anak yang memiliki kecerdasan interpersonal cenderung mudah memahami orang lain. Mereka sering memimpin di antara teman-temannya. Anak yang cerdas dalam interpersonal pandai mengorganisasi teman-teman mereka dan pandai mengomunikasikan keinginan kepada orang lain. Mereka memiliki perhatian yang besar kepada teman sebayanya sehingga acapkali mengetahui berita-berita yang berkembang di seputar mereka.

Peran guru dan orang tua dalam membantu mengembangkan kecerdasan intrapersonal anak dapat dilakukan dengan menjalin komunikasi yang baik dengan anak-anak. Model permainan yang memperkenalkan beragam emosi dan perasaan serta identifikasi diri yang sebenarnya, menurut kaca mata anak, perlu dikembangkan. Selain itu, pengakuan akan keberadaan "gaya belajar " anak mutlak untuk diciptakan. Oleh karena itu, kesempatan untuk menyelesaikan tugas-tugas secara mandiri tetap diperlukan di samping dorongan untuk bekerja sama dengan teman secara berpasangan dan kelompok .

Terkait dengan upaya membantu anak mengembangkan kecerdasan intrapersonal, beberapa strategi dalam upaya mengembangkan kecerdasan tersebut dapat dilakukan sebagai berikut ini: (a) membantu anak menciptakan citra diri positif; (b) menciptakan suasana kelas yang mendukung pengembangan kemampuan intrapersonal dan penghargaan diri anak; (c) membantu anak menuangkan isi dan curahan hati ke dalam buku harian; (d) bercakap-cakap memperbincangkan kelemahan, kelebihan dan minat anak; dan (e) mengajak anak berimajinasi menjadi satu tokoh dari sebuah cerita.

Ditinjau dari peranan guru dan orang tua dalam membantu mengembangkan kecerdasan naturalis, ditegaskan bahwa terdapat beberapa cara yang dapat dilakukan guru untuk mengembangkan kecerdasan itu. (a) guru dapat mengajak anak-anak menikmati dan mengamati alam terbuka. Pembelajaran dapat dilakukan di luar kelas; (b) guru dapat menyediakan materi-materi yang tepat untuk naturalis, seperti membiasakan menyiram tanaman di halaman TK setiap pagi, menanam bijibijian dalam media yang mudah dan mengamati pertumbuhannya;(c) guru dapat menciptakan permainan dan program pembelajaran yang berkaitan dengan unsurunsur alam, seperti membandingkan berbagai bentuk daun dan bunga, mengamati perbedaan tekstur pasir, tanah dan kerikil, mengoleksi biji-bijian dan menirukan karakteristik binatang tertentu; dan (d) guru dapat menyediakan buku-buku dan VCD yang memuat seluk-beluk hewan, alam, dan tumbuhan dengan gambargambar yang bagus dan menarik.

Kecerdasan naturalis memiliki peranan yang sangat besar dalam kehidupan. Pengetahuan anak mengenai alam, hewan, dan tumbuh-tumbuhan dapat mengantarkan mereka ke berbagai profesi strategis, seperti dokter hewan, insinyur pertanian, perkebunan, kehutanan, kelautan, ahli farmasi, geodesi, geografi dan ahli lingkungan hidup. 


\section{DAFTAR PUSTAKA}

Amstrong, T. (2009) Multiple Intelligences in the Classroom. Alexandria: ASCD.

Gardner, H. (1999). Intelligence Reframed: Multiple Intelligences for the 21st Century. New York: Basic Books.

Gardner, H. (2006). Multiple Intelligences: New Horizons in Theory and Practice. New York: Basic Books. 